SOME UNSTMUETRICAL ARYL SULFIDES

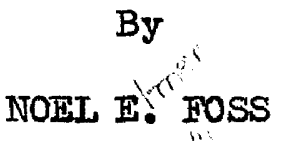

\title{
LIBRARY, UNIVERSITY OF MARYLAND
}

\footnotetext{
Thesis submitted to the Faculty of the Graduate School

of the University of Maryland in partial fulfillment of the reguirements for the degree of Doctor of Philosophy
} 
UMI Number: DP70017

All rights reserved

INFORMATION TO ALL USERS

The quality of this reproduction is dependent upon the quality of the copy submitted.

In the unlikely event that the author did not send a complete manuscript and there are missing pages, these will be noted. Also, if material had to be removed, a note will indicate the deletion.

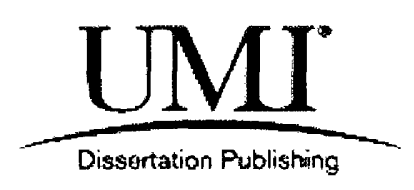

UMI DP70017

Published by ProQuest LLC (2015). Copyright in the Dissertation held by the Author.

Microform Edition (c) ProQuest LLC.

All rights reserved. This work is protected against unauthorized copying under Title 17, United States Code

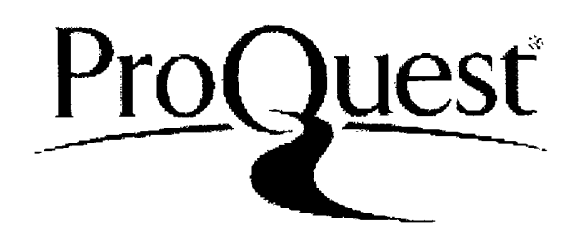

ProQuest LLC.

789 East Eisenhower Parkway

P.O. Box 1346

Ann Arbor, Ml $48106-1346$ 
ACKNOWLEDGMENT

The author wishes to express his appreciation of the advice and assistance given by Dr. Glenn L. Jenkins and Dr. J. H. F. Dunning, under whose direction this work has been carried out. He is also indebted to Drs. Du Mez, Vanden Bosche, Broughton, Drake, Haring and White for their valuable instruction. Special thanks are due Professor M. R. Thompson for his assistance in the pharmacological studies of the compounds, and Dr. David I. Macht and Mr. Irvin IaBuff, of Hynson, Westcott and Dunning, Inc., for their assistance in the toxicological and bacteriological examination of the compounds.

The author desires to acknowledge his thanks to Dr. H. A. B. Dunning for the generous grant of funds which has made this work possible, and for the unlimited use of the laboratories of Hynson, Westcott and Dunning, Inc. 


\section{INTRODUCTION}

It has long been recognized that phenol and its derivatives possess bactericidal properties. As is well known, the seat of bactericidal activity in such compounds lies in their phenolic hydroxyl groups and for maximum activity this group must not be blocked. Direct substitution in the ring, on the other hand, often enhances the bactericidal activity of the original phenol. ${ }^{1}$ The clinical results of hexylresorcinol ${ }^{2}$

$$
\left(\mathrm{HO}<\mathrm{CH}_{2} \mathrm{CH}_{2} \mathrm{CH}_{2} \mathrm{CH}_{2} \mathrm{CH}_{2} \mathrm{CH}_{3}\right.
$$

as a specific urinary antiseptic serve as an example of this hypothesis. More recently it has been discovered that hydroxydiphenylsulfides ${ }^{3,-}$ $4,5,6,7,8$,

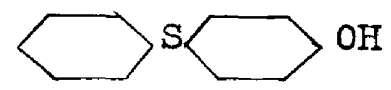
possess greater germicidal activity than that shown by the most active members of the phenol family. Since this unusual activity appeared to be due to the sulfur linkage, it was felt that the introduction of the ureide group into the ring of the phenolic sulfides would cause compounds of this nature to act as urinary antiseptics, as, in general, ureides are excreted by the kidney. That our deductions were not entirely amiss may be attested by the fact that the compounds prepared were eliminated through the urine. However, these results emphasize the danger of reasoning by analogy, for these same compounds failed to show the desired germicidal activity. 


\section{$-2-$}

A consideration of these facts led to the preparation of some derivatives and analogues of 4 -urea phenglsulfide-R

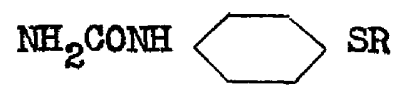

where $R$ may be phenol, resorcinol, metacresol or thymol. That this conclusion is justifiable, attention may be called to a number of sulfur derivatives of this nature which have already been prepared.

Sulfur has long been recognized to have parasiticidal properties. When taken internally, it is absorbed in the intestines and partly eliminated through the kidneys in the form of sulfates. 9 The sulfates combine with many toxins and thus act as detoxifying agents through the formation of harmless substances.

Dyson $^{10}$ calls our attention to the fact that little work has been done on the diphenyl residues which would throw light on their physiological properties. A review of the literature reveals the fact that practically no attention has been paid to the possibilities of aryl sulfides as therapeutic compounds. Furthermore, our knowledge of the chemistry of the aryl sulfides is very limited.

Recently Johnson and Hilbert ${ }^{3}$ have investigated the isomeric hydroxydiphenyl sulfides as germicidal agents. They found that the germicidal activity increased in the order of ortho, meta, and para substitution in agreement with the work of Schaeffer and Tilley ${ }^{11}$ on the isomeric cresols and cyclohexanols. A comparison of the results obtained from p-hydroxydiphenyl sulfide and p-hydroxydiphenyl sulfone indicates that the sulfide 
linkage is more favorable than the sulfone linkage for augmenting bactericidal activity of these hydroxydiphenyl sulfides, the p-hydroxydiphenyl sulfide showed the greatest activity. It has a phenol coefficient of 115. Even dilutions of 1:12,000 kill Bacillus typhosus on an exposure of 12.5 minutes. The minimum lethal dose for rabbits is $1.5 \mathrm{gm}$. per pound. Thus the compound has a very high chemotherapeutic index.

Johnson and Bass ${ }^{4}$ have had less success with iodinated diphenyl sulfide phenols as antiseptics. These halogenated members are extremely insoluble in water and consequently did not exhibit any pronounced bactericidal properties. Saturated solutions of the iodinated compounds in water, $5 \%$ alcohol, and $20 \%$ alcohol were wi thout effect on Bacillus typhosus as compared with phenol in the seme solvents.

Dunning, Dunning and Drake ${ }^{5}$ have prepared a number of symetrical organic sulfides and tested their bactericidal properties. Their results indicate that the symetrical sulfides exhibit a killing power approximateIy ten times as great as the analogous phenols (except in the case of resorcinol). For exemple, thymol, under the conditions of their test, kills Staphylococcus aureus in a dilution of 1:1000 in five minutes; whereas thymol sulfide kills in a dilution of 1:10,000 in five minutes. Due to a difference in the methods of testing, these values cannot be compared with those found by Johnson and his coworkers. Moness, Braker and Christiansen ${ }^{6}$ have made a study of the effect of 
various groups introduced into the hydroxyaromatic thioethers. Their data indicates that the mercuration of the hydroxyaromatic thioethers does not enhance the bactericidal activity of the thioether itself. Suter and Hansen ${ }^{7}$ have made a study of a series of p-hydroxyphenyl n-alkyl sulfides, the alkyl groups varying from methyl to hexyl. Their determinations show that the n-butyl and n-amyl compounds exhibit the highest activity toward Bacillus typhosus, while the n-hexyl compound is the most effective of the series toward Staphylococcus aureus. In every case the thioether shows a greater activity than the corresponding ether, the enhancement varying from two to five times.

Miller and Read ${ }^{8}$ have more recently investigated the bactericidal properties of aliphatioaromatic thioethers. They find that the same relation holds for thioalkyl phenols as for alkyl phenols; namely, that the phenol coefficient increases with the length of the side chain and that the normal side chain is more active than the corresponding branched chain. They differ, however, in the effect of position isomerism, as shown by the isomeric hydroxyphenylbutyl sulfides.

The present investigation is concerned with a number of 4-urea phenyl sulfide phenols, where the phenol may be phenol, resorcinol, metacresol, or thymol. p-nitrophenylsulfide phenols have been prepared by the method of Zincke and Lenhart. 12 The nitro compounds have been reduced by the hydrogen platinum catalyst method ${ }^{13}$ to the corresponding amines. The amines have been converted into the ureides by condensation with cyanic acid. The 
acetates, brom derivatives and azo dyes have been prepared for a better characterization of the compounds.

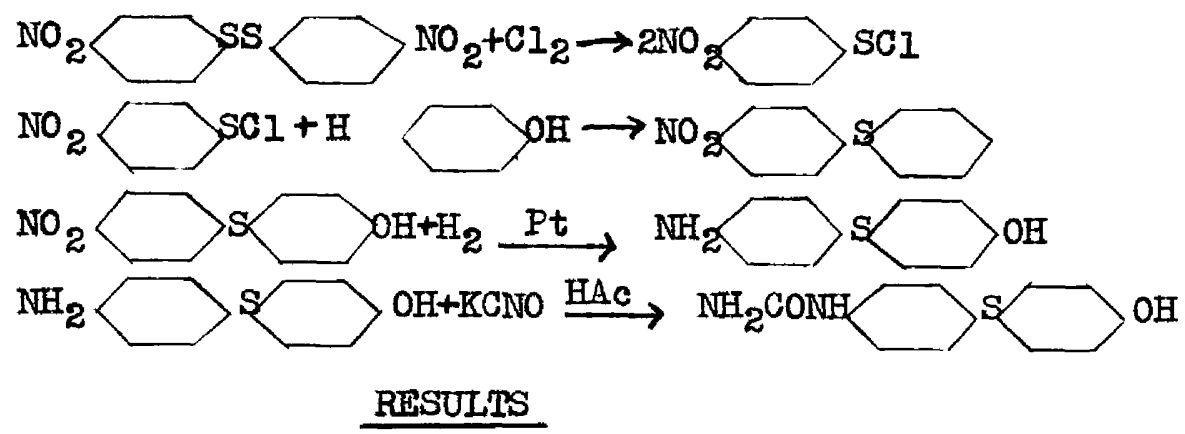

The colors of the various salts followed the usual nitro amino sequence. The nitro compounds were a deep yellow as were their brom derivatives. The reduction of the nitro compound to the amino compound resulted in a pure white compound, as were also its derivatives and the ureide. However, concentrated alcoholic or benzene solutions of all these sulfides yielded deep yellow-colored solutions, irrespective of the color of the dry salt.

The acidity of the phenolic hydroxyl group and the basicity of the amino group in the respective compounds were in accord with the results found by other investigators for similar diphenyl ethers. The nitro substituted phenolic thioethers were soluble in cold $10 \%$ sodium hydroxide but only partially soluble in concentrated amonium hydroxide. The amino substituted phenolic compounds were easily soluble in dilute sodium hydroxide but only slightly soluble in amonium hydroxide. The amines were slightly soluble in dilute hydrochloric acid and moderately soluble in hot concentrated hydrochloric acid, indicating that the amine group is 
weakly basic. The ureides were insoluble in acids and only with difficulty were they made to form 1:1000 solutions of their sodium salts by adding the calculated amount of alkali. All of the compounds with the OH groups unsubstituted gave the characteristic purple color then tested with $\mathrm{FeCl}_{3}$

The bacteriological tests were made with both Staphylococcus aureus and Bacillus typhosus. According to the theory that germicidal activity is a function of the lipoid solubility and hence inversely proportional to the solubility in water, one would expect these compounds to have a very high phenol coefficient. However, the bactericidal results have not been very satisfactory, due to the extreme difficulty of getting into solution the compounds to be tested.

The pharmacological determinations have been somewhat more noteworthy. They were carried out on the cat and rabbit. At least it was demonstrated that the compounds tested were eliminated in the urine and that they were non-toxic in any concentration in which they might appear in the blood after oral administration.

In order to better correlate the results, this report has been divided into three sections: In the first part there is outlined the chemical preparation of the sulfides and a description of their chemical and physical properties. In the second part there is reported the bactericidal tests and their apperent significance. In the third part there is reported the animal experiments and a discussion of the pharmacological action of the 
compounds prepared.

\section{PART I}

HRYL SULFIDE FHEIOLS

There are several procedures by which bydroxjdiphenyl sulfides have been synthesized. The symmetrical di-aryl sulfides were first prepared by Tassinari ${ }^{14}$ by treating a cold carbon di-sulfide solution of a phenol with sulfur dichloride:

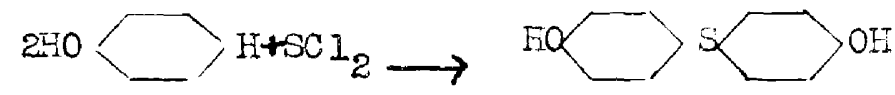

Dunning et al employed this rethod in the preparation of their substituted symetrical sulfides.

Finsberg ${ }^{15}$ prepared 4-hydroxydiphen+r sulfide by treating phenol With benzene sulfinle acid:

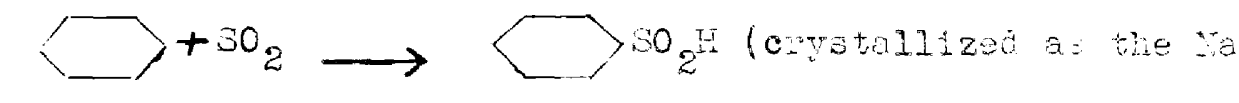

\section{2}
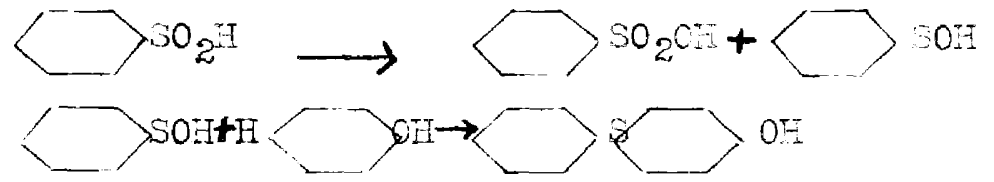

He was unsuccessful in isolating the phenol and described it as an uncrystalizizable oil. Its fomation was later reported by Knoevenagel and Polack, ${ }^{16}$ by Bourgeois, ${ }^{17}$ and by Lecher ${ }^{18}$ by the action of phenylsultochioride on Grignard reagent.

Johnson and Hiloert modified Hinsberg's reacton sligintly and oy dealkylation of the methyl ether of the pherol succeded in identitying the pure 4-hydroxydiplewyl sulfide in crystelinge fom. 
Zeigler ${ }^{19}$ showed that thiophenols do not react with diazonium salts in a manner analogous to phenols, but combine to give diazo ethers which break down at $70^{\circ}$ to give nitrogen and an aromatic sulfide:

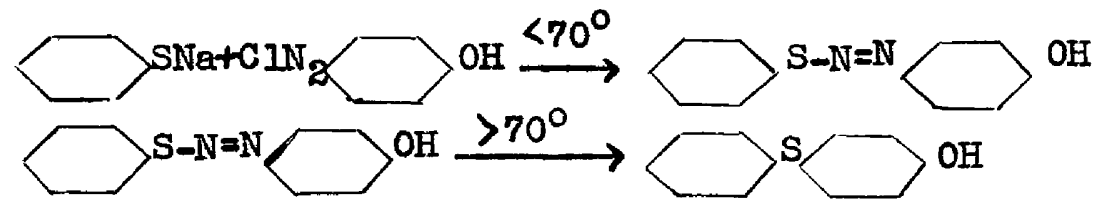

Mauthner reported no success with this reaction. Johnson and Hilbert modified the Zeigler reaction by treating the phenols with diazotized anisidines instead of diazotized aminophenols and obtained the methoxydiphenyl sulfides in good yields. If the diazonium salts were unstable at $70^{\circ}$, they added powdered copper, which acted as a catalyst for the reaction. The resulting methoxydiphenyl sulfide was hydrolyzed by the use of hydrobromic acid.

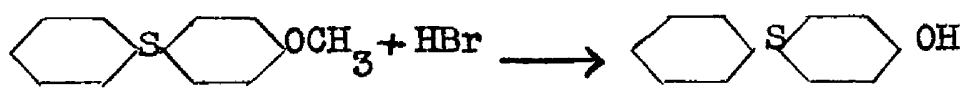

Leuckart $^{21}$ prepared p-hydroxydiphenyl sulfide by converting thiohydroquinone to the lead salt through lead acetate and heating it in alcoholic suspension with ethyl iodide:

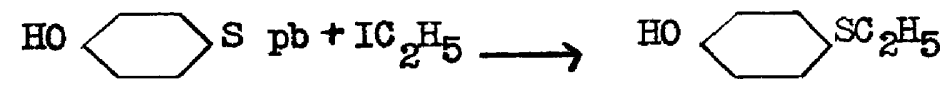

Miller and Read modified this method by using the monosodium salt of thiohydroquinone in methyl alcohol solution and report it as being more effective than the lead salt.

The method here reported is essentially that of Zincke and Lenhart. 12 4,4'dinitrodiphenyldisulfide was prepared from sodium disulfide and 1,4nitrochlorbenzene. 4-nitrophenylsulfurchloride was formed by passing 
chlorine into a dry chloroform suspension of 4,4'dinitrodiphenjldisulfide. The 4-nitrophenylsulfurchloride readily reacted with phenol to give 4-nitro 4'hydroxydiphenylsulfide. The course of the reactions may be indicated as follows:

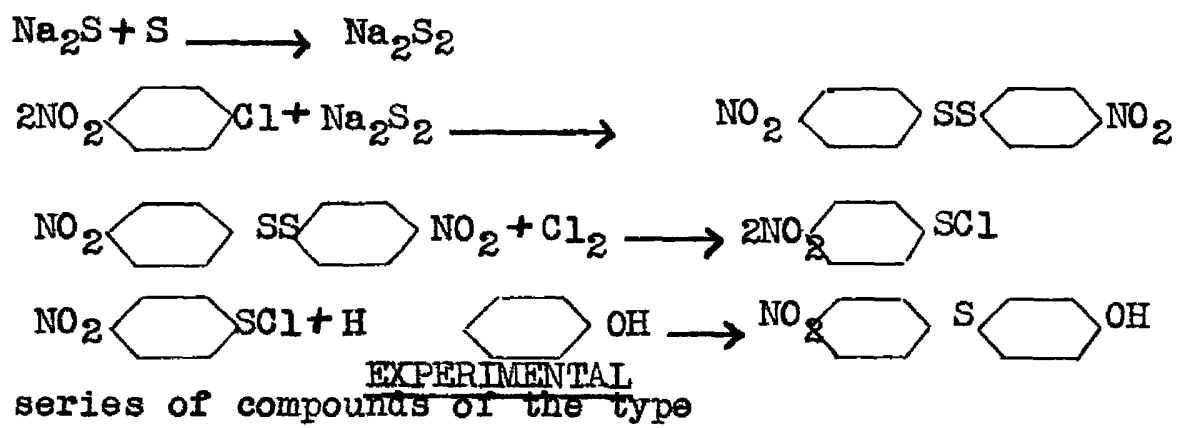

Four series of compounds or the type

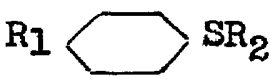

have been prepared where $R_{1}$ may be $\mathrm{NO}_{2}, \mathrm{NH}_{2}$, or $\mathrm{NH}_{2} \mathrm{CONH}$, and $\mathrm{R}_{2}$ may be phenol, resorcinol, metacresol, or thymol. Since the methods of preparation are uniformly applicable to any of the series, only one example, that where $R$ is phenol, will be given. The other members, together with their physical constants and analyses, are shown in the accompanying tables.

\section{4,4'ainitrodiphenyldisulfide}

This compound was prepared according to the method of Wohlfort, 22 and Blanksma ${ }^{23}$ later worked out in detall by Bogert and Stull ${ }^{24}$ in the preparation of 2,2'dinitrodiphenylsulfide. A three-necked flask was set up with a stirring apparatus, reflux condenser and soparatory funnel. One hundred sixty grams ( $\frac{1}{2}$ mole) of 1,4-nitrochlorbenzene was dissolved in 250 c.c. of alcohol by the aid of heat. A solution of sodium di- 
sulfide was prepared by adding $24 \mathrm{gm}$. ( $\frac{3}{4}$ mole) of sulfur to $180 \mathrm{gm}$. of $\mathrm{Na}_{2} \mathrm{~S} \cdot 9 \mathrm{H}_{2} \mathrm{O}\left(\frac{3}{4}\right.$ mole) dissolved in $200 \mathrm{c.c}$. of hot water. To this aqueous sodium disulfide solution was added $1500 \mathrm{c.c}$. of hot alcohol and the resulting solution filtered while hot to free of any unreacted sulfur. This aqueous-alcoholic solution of sodium disulfide was slowly added through the separatory funnel to the warmed alcoholic solution of nitrochlorbenzene with rapid stirring. The precipitate of crude 4,4 'dinitrodiphenyldisulfide was isolated and crystallized from hot benzene. $70 \mathrm{gm}$. (45\% yield) of light yellow crystals, melting at $170-173^{\circ}$, were obtained. It might be well to state that there are conflicting reports as to the melting point of the compound. 25

$$
\begin{array}{lll}
\text { Analyses: } & \text { Calculated for } \mathrm{C}_{12} \mathrm{H}_{8} \mathrm{O}_{4} \mathrm{~N}_{2} \mathrm{~S}_{2} & \mathrm{~S}=20.77 \\
& \text { Found } & \mathrm{S}=20.40
\end{array}
$$

The use of 1,4 nitrobrombenzene instead of 1,4 nitrochlorbenzene did not materially alter the yield. Rapid stirring and the slow addition of the sodium sulfide solution did increase the yield.

\section{4-nitro 4'hydroxydiphenylsulfide}

4-nitrophenylsulfurchloride was prepared according to the method of Zincke and Lenhart by passing chlorine into an anhyorous chloroform suspension of the yellow 4,4'dinitrodiphenylsulfide. As the reaction proceeded, the disulfide crystals dissolved and an orange-red solution was formed. No attempt was made to isolate the 4-nitrophenylsulfurchloride 
which was described by zincke $e^{12}$ as being very unstable. It was immediately added to a dry ether solution of phenol. Heat was given off and copious fumes of hydrogen chloride were evolved during the react i... The mixture was refluxed on a water bath for several hours to drive off the excess hydrogen chloride. A yellon precipitate appearec ard wes filtered off. On recrystallization from benzene this pioved to be the original 4,4'dinitrodiphenylsulfide, corresponding to sbout $9 \%$ of the original procuct.

To the cold ether chloroform filtrate was added about tmo volumes of petroleum ether and the solution was set in the ice-box overnight. A crop of yellow crystals appeared the next morning. These were recrystallized from ether and petroleum benzene several tines anc finally from alcohol and water. Fine yeliow crystels corresponaine to a yield of $21 \%$ were obtained. Their melting point was $151-152^{\circ}$ as compared with

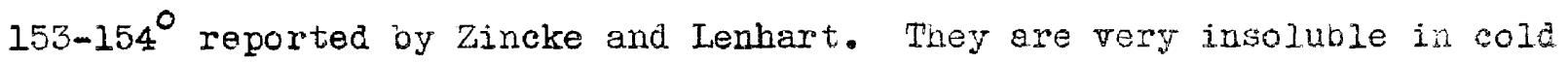
water, sliently soluble in hot water, and reacily soluble in alcohol, acetone, ether, acetic acid anà benzene. They give a red-brom solution when dissolved in alkali.

$$
\begin{array}{lll}
\text { Analyses: } & \text { Calculated for } \mathrm{C}_{12 \mathrm{H}_{9} \mathrm{O}_{4} \mathrm{NS}} & S=12.95 \\
& \text { Found } & S=13.01
\end{array}
$$

With the hope of increasing the yield, oromive ras used instead of chlorine in splitting the 4,4'dinjtrodiphenyldisulfide. On tre edaition of phenol, a vigorous reaction tool lace and a voluninols vellow preaipi- 
tate appeared. This precipitate, however, turned out to be the original disulfide, corresponding to a 95\% recovery, indicating that bromine was unsuitable for this reaction under the conditions of the experiment.

\section{4-nitro 3',5'dibrom 4' hydroxydiphenylsulfide}

This was prepared by adding the calculated amount of bromine to a cold glecial acetic acid solution of 4-nitro $4^{\prime}$-hydroxydiphenylsulfide. The solution was slightly warmed to complete the reaction. On asplrating with air, a crystalline precipitate appeared. Recrystallization from alcohol and water and subsequently from benzene and petroleum $\theta$ ther yielded yellow crystals, melting at $155-156^{\circ}$. They are insoluble in water or petroleum benzene, but are easily soluble in aleohol, acetone, ether and alkali.

$\begin{array}{lll}\text { Analyses: } & \text { Calculated for } \mathrm{C}_{12} \mathrm{H}_{7} \mathrm{O}_{3} \mathrm{NSBr}_{2} & \mathrm{~S}=8.00 \\ & \text { Found } & \mathrm{S}=8.09\end{array}$

\section{4-nitrodiphenylsulfide $4^{\prime}$ acetate}

The acetate was prepared by the well-known method of refluxing the 4-nitro 4'hydroxydiphenylsulfide with acetic anhydride and anhydrous sodium acetate. The product was crystallized from alcohol and hot water and then. from benzene and petroleum ether. They are white crystals with a slight yellow tinge and have a melting point of $80.5-81.5^{\circ}$, which checks with the 
melting point given by Zincke. They are very insoluble in cold water, slightly soluble in hot water, and easily soluble in the usual organic solvents of alcohol, acetone, ether and benzene. The compound is not hydrolyzed in the cold either in dilute alkali or dilute acid.

$$
\text { Analyses: } \begin{array}{ll}
\text { Calculated for } \mathrm{C}_{14} \mathrm{H}_{11} \mathrm{O}_{4} \mathrm{NS} & \mathrm{S}=11.09 \\
\text { Found } & \mathrm{S}=11.15
\end{array}
$$

\section{4-amino 4'hydroxydiphonylsulfide}

An attempt to reduce the nitro compound by means of stannous chloride and hydrochloric acid proved unsatisfactory due to the loss of amine when precipitating the tin with hydrogen sulfide. The Adams hydrogen platinum catalyst method ${ }^{13}$ proved very much more satisfactory for preparing the amine. As is well known, the nitro compound must be very pure for the method, as small amounts of sulfur impurities readily poison the catalyst. Twenty-seven grams of nitro compound were dissolved in $270 \mathrm{c.c}$. of 95\% ethyl alcohol. Three-tenths of a gram of platinum dioxide (corresponding to $1 \%$ by weight of the nitro compound) was added as a catalyst. The mixture was set up in a mechanical shaking apparatus and connected with a hydrogen pressure tank. During the reduction much heat was given off. The color of the solution changed from a deep yellow through green to a yellow-brown. After the solution had taken up the calculated amount of hydrogen, the supernatant liquid was decanted from the platinum catalyst and filtered through the filter cell to free from platinum. Impure brown 
crystals were obtained by distilling the alcohol under reduced pressure at a temperature not exceeding $65^{\circ}$. These were purified by boiling the alcoholic solution of the erystals with norite and adding water to the filtrate. Twenty-two grams of crystals, having a melting point of 151$152^{\circ}$, were obtained, corresponding to a yield of $86 \%$. They are slightly soluble in hot water, readily soluble in alkali to give a brown solution when in sufficient concentration, and fairly soluble in hot acid solution but less soluble in cold acid solution. They are extremely soluble in the common organic solvents but are insoluble in petroleum ether.

\begin{tabular}{|c|c|}
\hline Anal & Calculated for $\mathrm{C}, \mathrm{H}$, ONS \\
\hline
\end{tabular}

The hydrochloride was obtained by passing dry hydrogen chloride into an anhydrous ether solution of the amine. It melted at $220^{\circ}$ with decomposition. It is only slightly soluble in water, readily soluble in alcohol and acetone, and insoluble in chloroform and cerbon tetrachloride.

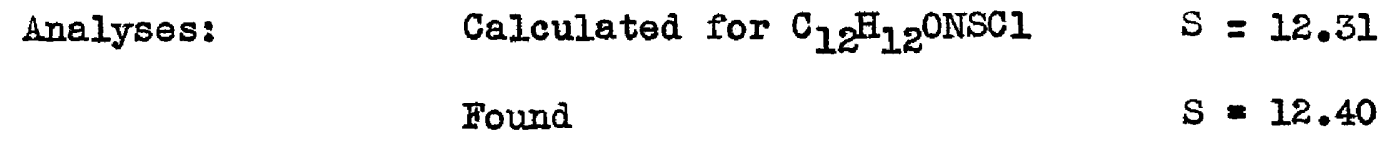

The Amine Coupled with R Salt

The azo dye was prepared by diazotizing the amine and coupling the resulting diazonium salt with 2-hydroxynaphthalene 3,6-disulphonic acid in acid solution. The dye is of a red color and is insoluble in acid solution. It is slightly soluble in water and readily soluble in alkali solution. 
$-15-$

Analyses: $\begin{array}{lll}\text { Calculated for } \mathrm{C}_{22^{H}} 17^{\mathrm{O}}{ }_{8} \mathrm{NS}_{3} & S=17.94 \\ & \text { Found } & S=15.42\end{array}$

\section{4-acetyleminoaiphenylsulfide $4^{\prime}$ acetate}

The diacetate was prepared in the usual manier by treating the amine with acetic anhyride and sodium acetate. The product was crystallized from alcohol and water and recrystallized from benzene anc petroleuri benzene. Small white crystals having a melting point of 158-159 separated. The compound is very insoluble in cold water, acid or alkali, is slightly soluble in hot water, and is readily soluble in alcokol, glacial acetic acid and hot benzene. The fact that it may be crystallized from boiling water without hydrolysis shows that it is a pairly stable acetate. inalyses:

Calculated for $\mathrm{C}_{16^{\mathrm{H}}}{ }_{15} \mathrm{O}^{\mathrm{NSS}}$

$S=10.18$

Found

$S=10.09$

\section{4-byäroxydiphenylsulfide 4'urea}

Two grams of potassium cyanate dissolved in $5 \mathrm{c.c}$. of water ar. cooled to $0^{\circ}$ was dropped into a solution of $4 \mathrm{gm}$. of the amine disselved in $30 \mathrm{c} . \mathrm{c}$. of $50 \%$ acetic acid cooled to $2^{\circ}$. The solution is repidly stirred for a few minutes and suddenly a mass of write crystals appear. The mixture is neated slightly to complete the reaction and filtered on a Buchner funnel. The crystals were purified by boiling in alcohol with norite anc were recrystallized from alcohol anc water. They melted sharply at $228-220^{\circ}$ and the yield was $2.5 \mathrm{gm}$. corresponding to $60 \%$ of the heoretical. They are 
very insoluble in cold water, slightly soluble in hot water, moderately soluble in cold alcohol and very soluble in hot alcohol, and readily soluble in acetone, ether and ethylene glycol. A 1:1000 solution of the sodium salt, made by adding the calculated amount of alkali, was soluble while hot, but precipitated after standing in the cold for several hours. However, the compound was readily soluble in $10 \%$ alkali. Analyses:

$$
\begin{array}{lll}
\text { Calculated for } \mathrm{C}_{13^{\mathrm{H}}}{ }^{\mathrm{O}} \mathrm{2}^{\mathrm{NS}} & \mathrm{S}=12.33 & \mathrm{~N}=10.75 \\
\text { Found } & \mathrm{S}=12.39 & \mathrm{~N}=10.76
\end{array}
$$

Several attempts were made to prepare $\longrightarrow \mathrm{S} \longrightarrow \mathrm{OH}$ by diazotizing the amino group and replacing the diazonium group with hydrogen. The amine was diazotized with sodium nitrite in an excess of hydrochloric acid and boiled with dilute alcohol. The solution turned a deep browish red color. A tar which could not be purified and a dye were isolated. This dye analyzed 12.83\% for sulfur. Apparently the diazonium salt must have coupled with itself to form an azo dye. Two possibilities suggest themselves here. The diazonium group of one molecule could couple with the amino group of another molecule of the same kind which had failed to diazotize, resulting in an amino-azo dyes or the diazonium group of one molecule could react With an hydrogen ortho to the hydroxyl group of another molecule of the same kind, yielding a phenolic azo dye. If both reactions should take place simultaneously, a very complex series of products would result. The diazotization was also carried out by suspending the hydrochloride of the amine on glacial acetic acid and adding the calculated amount of 
butyl nitrite. The diazonium salt was precipitated by adding ether, the precipitate filtered off and quickly transferred to a boiling solution of dilute alcohol. Again only a red dye was isolated.

Attempts to replace the diazotized amino group with the hydroxyl group by boiling with water proved just as unsatisfactory. Apparently the compound must have the hydroxyl group blocked before the diazonium group can be replaced, as is necessery with aminophenols.

In the analytical calculations, sulfur and chlorine were determined by the well-known Parr-bomb method. Nitrogen analyses were made by the Gunning modificetion ${ }^{26}$ of the Kjeldahl method. Melting point determinations were made in the usual manner and were not corrected.

By application of the technique described in the preceding preparations, the compounds shown in Table I were prepared.

\section{PART II}

BACTERIOTOGICAL

Due to the extreme insolubility of the compounds, it was difficult to obtain any definite bacteriological data. All the phenolic sulfur ureides were soluble in water less than 1:10,000, except the resorcinol derivative, which was soluble in water about 1:1000: Even in 30\% alcohol solution, the same degree of solubility existed. 1:1000 solutions of the ureides finally were obtained by using $50 \%$ ethylene glycol as a solvent. The thymol derivative showed bactericidal activity at this dilution 
TABLE I-A

Phenol Series

\begin{tabular}{|c|c|c|c|c|c|c|c|c|}
\hline \multirow[b]{2}{*}{ Compound } & \multirow{2}{*}{$\begin{array}{c}\text { Melting } \\
\text { Point }\end{array}$} & \multicolumn{2}{|c|}{ Sulfur } & \multicolumn{2}{|c|}{ Nitrogen } & \multicolumn{3}{|c|}{ Solubility } \\
\hline & & Calcd & Anal. & कelct & Anai & $\mathrm{NaOH}$ & ${ }_{2^{H}}{ }^{\mathrm{CH}}$ & $\mathrm{C}_{6} \mathrm{H}_{6}$ \\
\hline $\mathrm{NO}_{2} \longrightarrow S \subset \mathrm{OH}$ & $150-151^{\circ}$ & 12.95 & 13.01 & & & Sol. & Sol. & Sol. hot \\
\hline $\mathrm{NO}_{2} \longrightarrow \mathrm{s}<\underset{\mathrm{Br}}{\mathrm{Br}_{\mathrm{H}}}$ & $155-156^{\circ}$ & 8.00 & 8.09 & & & Sol. & Sol. & Sl. sol. \\
\hline$\supset S<{ }^{\circ} \mathrm{OCOH}_{3}$ & $80.5-81.5^{\circ}$ & 11.09 & 11.15 & & & Insol. & Sol. & Sol, hot \\
\hline$\supset \mathrm{OH}$ & $151-152^{\circ}$ & 14.75 & 14.80 & & & Sol. & Sol. & Sl. sol. \\
\hline${ }^{\mathrm{HO}}{ }_{3}^{\mathrm{S}} \sum^{\mathrm{OH}}=\mathrm{N}$ & & 17.94 & 15.42 & & & Sol. & Insol. & Insol. \\
\hline$>S \longrightarrow \mathrm{OaCH}_{3}$ & $158 \cdot 5-159^{\circ}$ & 10.63 & 10.68 & & & Insol. & Sol. & Sol. hot \\
\hline $\mathrm{NH}_{2} \mathrm{CONH}<$ & $228-229^{\circ}$ & 12.29 & 12.25 & 10.75 & 10.76 & $\begin{array}{c}\text { Sl. sol. } \\
\text { hot }\end{array}$ & Sol. hot & Sol. hot \\
\hline
\end{tabular}

(a) and (b) - These compounds have been prepared by other investigators. See reference No. 12. 
TABLF I-B

Resorcinol Series

(a)

\begin{tabular}{|c|c|c|c|c|c|c|c|c|}
\hline \multirow{2}{*}{ Compound } & \multirow{2}{*}{$\begin{array}{l}\text { Melting } \\
\text { Point }\end{array}$} & \multicolumn{2}{|c|}{ Sulfur } & \multicolumn{2}{|c|}{ Nitrogen } & \multicolumn{3}{|c|}{ Solubility } \\
\hline & & palc'd & Ang1. & क्वाcत. & Ang1. & $\mathrm{NaOH}$ & ${ }^{2}{ }_{5} \mathrm{OH}$ & $\mathrm{F}_{6} \mathrm{H}_{6}$ \\
\hline$\Rightarrow S \longrightarrow \mathrm{OH}$ & $184-185^{\circ}$ & 12.16 & 12.20 & & - & Sol. & Sol. & Sol, hot \\
\hline $\mathrm{NO}_{2} \smile \mathrm{OH}_{\mathrm{Br}}^{\mathrm{Br}_{\mathrm{H}}}$ & $179.180^{\circ}$ & 7.60 & 7.76 & & & Sol. & Sol. & Sol. \\
\hline$\Rightarrow s=000 \mathrm{CH}$ & $110-111^{\circ}$ & 9.19 & 9.25 & & & Insol. & Sol. & Sol. hot \\
\hline $\mathrm{NH}_{2} \longrightarrow \mathrm{OH}$ & $151-152^{\circ}$ & 13.73 & 13.80 & & & Sol. & Sol. & Sol. \\
\hline${ }_{3}^{\mathrm{HO}_{3} \mathrm{~S}} \mathrm{OH}^{\mathrm{N}=\mathrm{N}}{ }_{\mathrm{OH}}^{\mathrm{S}}$ & & 17.51 & 17.31 & & & Sol. & SI. sole & Insol. \\
\hline $\mathrm{CH}_{3} \mathrm{CONH} \longrightarrow \mathrm{S}=\mathrm{OCHH}_{3}$ & $158-158.5^{\circ}$ & 8.91 & 8.84 & & & Insol. & Sol. & Sol. hot \\
\hline $\mathrm{NH}_{2} \mathrm{CONH} \longrightarrow \underset{\mathrm{OH}}{\longrightarrow} \longrightarrow \mathrm{OH}$ & $178-178.5^{\circ}$ & 11.59 & 11.59 & 10.14 & 10.03 & Sol. not & Sol. & Sol, hot \\
\hline
\end{tabular}

(a) and (b) - These compounds have been prepared by other investigators. See reference No. 12. 
TABIE I-C

Metacresol Series

\begin{tabular}{|c|c|c|c|c|c|c|c|c|}
\hline \multirow[b]{2}{*}{ Compound } & \multirow{2}{*}{$\begin{array}{l}\text { Melting } \\
\text { Point }\end{array}$} & \multicolumn{2}{|c|}{ Sulfur } & \multicolumn{2}{|c|}{ Nitrogen } & \multicolumn{3}{|c|}{ Solubility } \\
\hline & & palc'd & Anal. & Calc'd & Anal. & $\mathrm{NaOH} \quad \mathrm{C}_{i}$ & ${ }^{2} \mathrm{H}_{5} \mathrm{OH}$ & $\mathrm{C}_{6} \mathrm{H}_{6}$ \\
\hline $\mathrm{NO}_{2} \longrightarrow \mathrm{S}_{\mathrm{CH}_{3}} \mathrm{OH}$ & $193-193.5^{\circ}$ & 12.29 & 12.25 & & & Sol. & Sol. & sol. hot \\
\hline $\mathrm{NO}_{2} \longrightarrow_{\mathrm{CH}_{3}}^{\mathrm{S}} \underset{\mathrm{Br}}{\mathrm{Br}}$ & $204-205^{\circ}$ & 7.60 & 7.59 & & & Sol. & Sol. & Sol. hot \\
\hline $\mathrm{NO}_{2} \longrightarrow \mathrm{CH}_{2} \mathrm{OCCH}_{3}$ & $98-99^{\circ}$ & 10.56 & 10.61 & & & Insol. & Sol. & Sol. hot \\
\hline $\mathrm{NH}_{2} \longrightarrow \mathrm{S}_{\mathrm{CH}_{3}} \mathrm{OH}$ & $149.5-150^{\circ}$ & 13.85 & 13.90 & & & Sol. & Sol. & Sol. hot \\
\hline $\left.\mathrm{HO}_{3}{ }_{3}^{\mathrm{S}}\right\}^{\mathrm{OH}}=\mathrm{N} \longrightarrow \mathrm{CHO}_{3}^{\mathrm{S}}$ & & 17.58 & 13.81 & & & Sol. & Insol. & Insol. \\
\hline $\mathrm{CH}_{3} \mathrm{CONH} \longrightarrow \mathrm{CH}_{3} \mathrm{OCCH}_{3}$ & $128-128.5^{\circ}$ & 10.22 & 10.30 & & & Insol. & Sol. & Sol. hot \\
\hline $\mathrm{NH}_{2} \mathrm{CONH} \rightleftharpoons \delta_{\mathrm{CH}_{3}} \mathrm{OH}$ & $201-201.5^{\circ}$ & 11.67 & 11.63 & 10.21 & 10.30 & Sol. not & Sol. & Sol, hot \\
\hline
\end{tabular}


TABIE I-D

Thymol Series

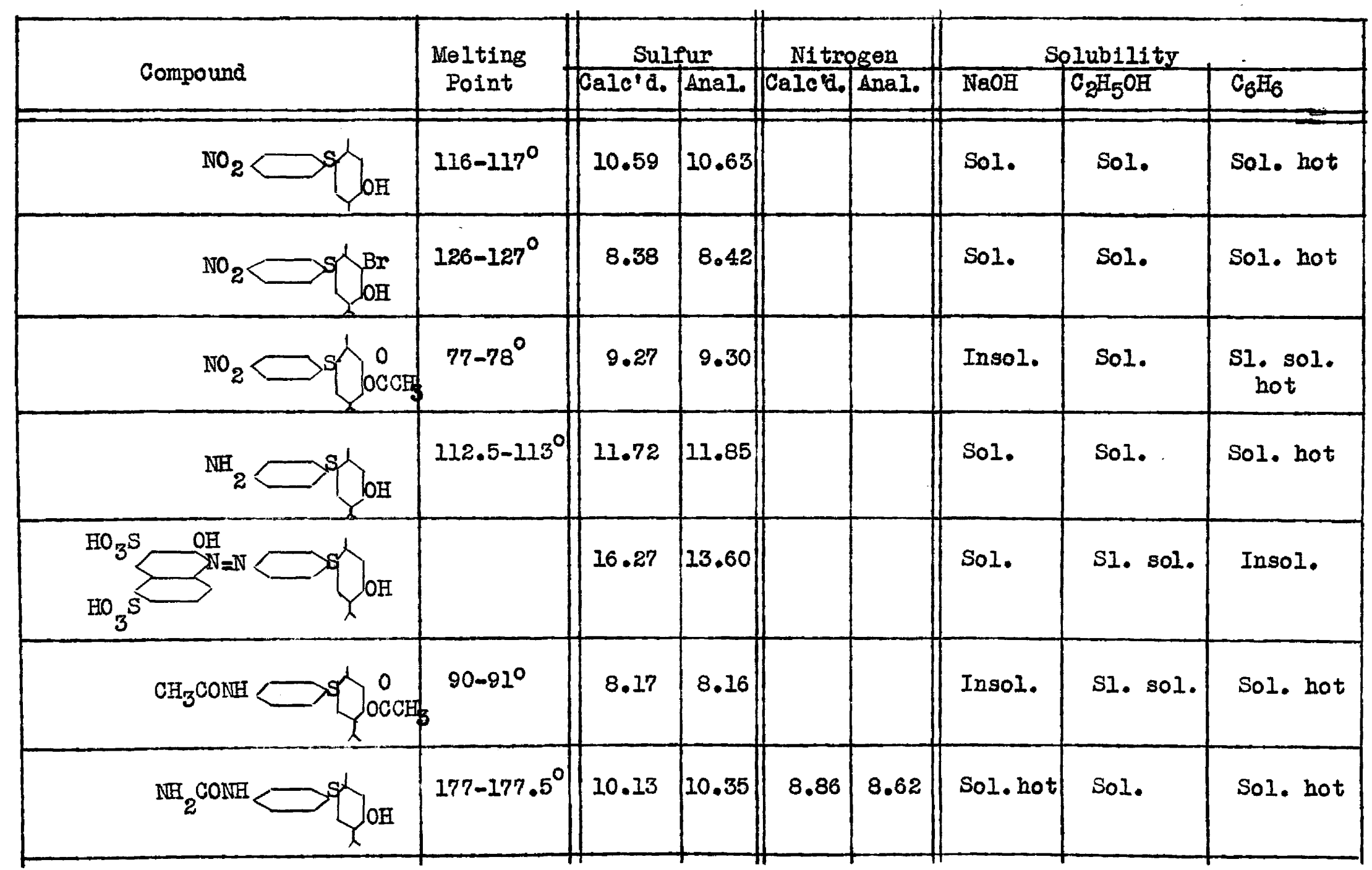


against Staphylococcus aureus as is indicated by Table II. The technique employed consisted of the United States Department of Agriculture method, which is essentially as follows: $0.5 \mathrm{c.c}$. of standard culture (Strain No. 209) was added to 5 c.c. of diluted antiseptic. Transfers were made with a $4 \mathrm{~mm}$. platinum loop wire from No. $23 \mathrm{~B}$. and S. gage wire. The culture medium used was a sterile nutrient beef extract broth, 10 c.c. being used in each suboulture tube. All dilutions were made with sterile distilled water.

More favorable results were obtained against Staphylococcus aureus when using the Cup-plate method. By this procedure only the resorcinol derivative failed to show any activity. The thymol derivative showed the largest zone.

$\begin{array}{lc}\text { Sulfur ureide } & \underline{\text { Zone }} \\ \text { Phenol } & 0.3 \mathrm{~cm} . \\ \text { Resorcinol } & \text { no zone } \\ \text { Metacresol } & 0.8 \mathrm{~cm} . \\ \text { Thymol } & 0.9 \mathrm{~cm} . \\ 50 \% \text { Ethylene glycol control no zone }\end{array}$

The Hygienic Laboratory method of procedure was as follows: 10 c.c. of agar was inoculated with a standard loop full of Staphylococcus aureus and poured into a sterile Petri dish. Using a sterile glass vial $1.5 \mathrm{~cm}$. in diameter, a depression was made in the center of the plate. 0.2 c.c. of the solution to be tested was introduced into the depression and 
TABIE II

Killing time in minutes for Staphylococcus aureus by $1: 1000$ solutions in $50 \%$ ethylene glycol after twenty-four hour readings.

\begin{tabular}{|l|c|c|c|c|c|c|c|c|c|c|c|c|}
\hline Sulfur Ureide & 5 & 15 & 30 & 45 & 60 & 75 & 90 & 105 & 120 & 135 & 150 & 165 \\
\hline \hline Phenol & + & + & + & + & + & + & + & + & + & + & + & + \\
\hline Resorcinol & + & + & + & + & + & + & + & + & + & + & + & + \\
\hline Metacresol & + & + & + & + & + & + & + & + & + & + & + & + \\
\hline Thymol & + & + & + & + & - & - & - & - & - & - & - & - \\
\hline Control & + & + & + & + & + & + & + & + & + & + & + & + \\
\hline
\end{tabular}

Killing time in minutes for Staphylococcus aureus by $1: 1000$ solutions in $50 \%$ ethylene glycol after forty-eight hour readings.

\begin{tabular}{|l|c|c|c|c|c|c|c|c|c|c|c|c|}
\hline Sulfur Ureide & 5 & 15 & 30 & 45 & 60 & 75 & 90 & 105 & 120 & 135 & 150 & 165 \\
\hline \hline Phenol & + & + & + & + & + & + & + & + & + & + & + & + \\
\hline Resorcinol & + & + & + & + & + & + & + & + & + & + & + & + \\
\hline Metacresol & + & + & + & + & + & + & + & + & + & + & + & + \\
\hline Thymol & + & + & + & + & + & + & - & - & - & - & - & - \\
\hline Control & + & + & + & + & + & + & + & + & + & + & + & + \\
\hline
\end{tabular}


TABIE III

Killing time in minutes for Bacillus typhosus, by 1:1000 solutions in $50 \%$ ethylene glycol, after twenty-four hour readings.

\begin{tabular}{|c|c|c|c|c|c|}
\hline Sulfur Ureide & 5 & 15 & 30 & 45 & 60 \\
\hline \hline Phenol & + & + & + & + & + \\
\hline Resorcinol & + & + & + & + & + \\
\hline Metacresol & + & + & + & + & + \\
\hline Thymol & - & - & - & - & - \\
\hline Control & + & + & + & + & + \\
\hline
\end{tabular}


the plate was incubated at $37.5^{\circ}$ for twenty-four hours.

Tests using Bacillus typhosus showed that only the thymol derivative exhibited any activity against this organism, as is evidenced by Table III. The same procedure as given above for Staphylococcus aureus was used. It will be noticed that the thymol derivative exhibited a greater germicidal activity agatnst Bacillus typhosus than Staphylococcus aureus.

\section{PART III}

\section{PHARMACOIOGICAL}

The results of these experiments have been divided into severel parts. The elimination of the ureides was first determined, followed by a discussion of their effects on respiration and blood pressure. The effects on the normal function of the body and toxicity tests have also been made. In order to determine the path of elimination of these ureides, 1 gm. of each ureide was given orally by capsule to a cat weighing approximately $1.65 \mathrm{~kg}$. and the urine was collected after one or two hours. In the use of the resorcinol ureide, the urine gave a positive test for resorcinol by a modification of the Selewinoff test for levulose. The resorcinol ureide in vitro also gave a positive test for this modified Selewinoff's reaction. From these facts, it was believed that the resorcinol ureide was eliminated through the kidneys. To further substantiate our conclusion, a 1:200 dilution of the sodium salt of the resorcinol administered to cats through the femoral vein was likewise detected in the urine. In fact, 
on collecting the urine from the bladder of the cat after death, a fine precipitate settled out which gave the melting point of the original ureide. Although there was not enough compound for an analysis, it was believed that the melting point determination was suficient to prove our conclusion that the compound was eliminated through the urine.

It appeared that the other ureides were eliminated in a manner similar to that of the resorcinol ureide. When given orally to cats in $1 \mathrm{gm}$. doses, they produced no apperent symptoms, but their presence in the urine was not definitely proved, inasmuch as no satisfactory test was worked out for testing them. However, when given intravenously in the form of their sodium salts, the presence of each ureide in the urine was definiteIy proved by melting point determinations of the precipitate coming out.

For the purpose of studying their effects on respiration and blood pressure, a 1:200 solution of the sodium salt was prepared by dissolving the ureide in the calculated amount of 0.1 normal sodium hydroxide and diluting to the required strength with hot distilled water. On cooling, part of the compound precipitated in a fine state of subdivision. 100150 c.c. of this dilution was injected by way of the femoral vein to anesthetized cats weighing $2.6-2.65 \mathrm{~kg}$. The carotid blood pressure and respiration were recorded by a chymograph in the usual manner.

It is significant to note that these ureides produced no effect on respiration or blood pressure provided that the rate of administration was not too rapid. Too fast a rate of administration caused a sharp drop in 


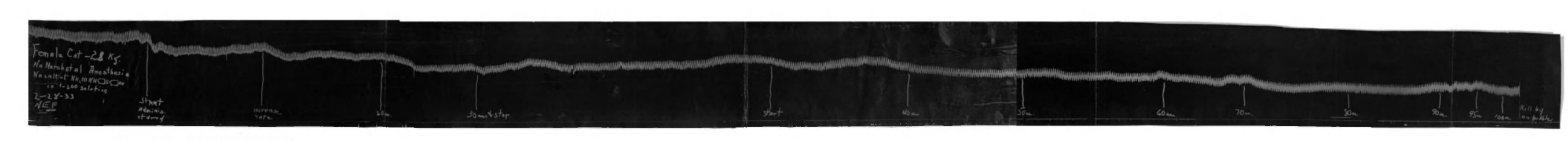

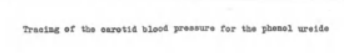





blood pressure and inhibition of respiration as is evident from the accompanying tracings. If the amount was not lethal, the blood pressure and respiration rapidly returned to normal. If the dose administered was too large, death was caused by respiratory failure, the heart continuing to beat after respiration ceased. The order of decreasing toxicity of the ureides by this mothod was thynol, metacresol, phenol and resorcinol. As the drug was administered, the above-mentioned circulatory shock (a property not uncommonto other related and mildly irritant compounds) diminished for all four ureides to a certain point. As, for instance, the metacresol compound could be injected at the rate of 0.3 c.c. per minute when the injection was first started, and by the time 80 c.c. had been administered, the rate of administration could be increased to 1 c.c. per minute without any noticeable effects. Since this transitory depressive effect was produced in no instance unless an intravenous rate of at least $4.5 \mathrm{mg}$. per minute was administered, it was concluded that relativeIy enormous doses given orally would be completely devoid of any circulatory effect.

If the bladder was emptied before the intravenous administration of the drug, it was observed that the bladder was again filled at the conclusion of the experiment when from 100-150 c.c. of solution had been administered. It was not attempted to explain this rapid excretion by the kidney to any diuretic properties the drug might have, since the large volume of liquid administered could of itself have caused this urine excretion. However, the large volume of urine excreted, together with the presence of the ureides 
in this urine conclusively proved that the ureides were rapidig elininated by the body through the kidney; for in no instance was an aninal Wlied by the intravenous administration of the arug regardess of the amount injected, provided the rate of administration vas not excessive. All of these ureides showed a very low toxicity. Five husdred milligrams, given in suspension by stomach tube to rabbits, produced no toxic efrect, no purgation, no diuresis, no hypnosis, no anesthesia and no excitement.

The pienoisulphouphthalein test was not afrected.

One gram doses administered orally on two successive days to cats weighing $3 \mathrm{~kg}$. likewise produced no apparent symptoms. Doses of 0.5 to 2.0 gm. introduced intravenously to cats in ro instance produced death when administered at an ordinary rate of $1 \mathrm{lcw}$.

\section{CONCLUSICI:}

Twenty-eici compouncs have been prepared. They are of tre generay nature $\mathrm{F}_{2} \longrightarrow \mathrm{SR} \mathrm{R}_{2}$, where $\mathrm{R}_{1}$ may be $\mathrm{NO}_{2}$, $\mathrm{NH}_{2}$, or $\mathrm{NH}_{2} \mathrm{CONH}$, and $\mathrm{R}_{2}$ ma be phenol, resor... dol, metacresol or thrmol. Sore brom dozivetives ard acetates have been made, as rell as azo dyes of the amines. Imenty-fown of these compounds have not been preriously descriced in tho Itrereture. The ureide deritatives heve been tested beteriolceicelly. Oniv the thymol ureide has bee found to have eng germicidal actipity, ard it ax-

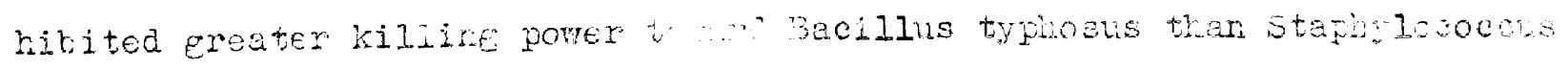


aureus.

The ureides have also been examined pharmacologically and it was show that they were excreted promptly by way of the urinary tract. It was further shown that they possess a low degree of toxicity and can be given in relatively large doses without any effect on the normal functions of the body. 


\section{BIBLIOGRAPHY}

(1) Johnson and Hodge, J. Amer. Chem. Soc., 35, 1014 (1913)

Johnson and Lane, Ibid., 43, 348 (1921)

Dohme, Cox and Miller, ibid., 48, 1688 (1926)

Talbot and Adams, ibid., 49, 2040 (1927)

Hamp1I, J. Infectious Diseases, 43, 25 (1928)

Rettger, Valley and Plartridge, Zentr. Bakt. Orig., 110, 80 (1929); (I) 111,287 (1929)

Klarmann, J. Amer. Chem. Soc., 48, 791 (1926; 48, 2358 (1926)

Rarmann and Von Wowern, Ibid., 51, 605 (1929)

Klarmann, Gatyar and Shternov, ibid., 53, 3397 (1931); 54, 298 (1932); 54, 1204 (1932)

Coulthard, Marshall and Pyman, J. Amer. Chem. Soc., 280, 1930

Read and Miller, J. Amer. Chem. Soc., 54, 1195 (1932)

(2) Leonard, J. Amer. Med. Assoc., 83, 2005 (1924)

Leonard, J. Urol., 12, 585 (1924)

Leonard and Wood, J. Amer. Med. Assoc., 85, 1855 (1925)

Henline, J. Urol., 14, 119 (1925)

Scott and Leonord, Amer. J. Dis, Children, 31, 241 (1926)

Wynne, Minn. Med., April, 156 (1926)

Brown, J. Amer. Med. Assoc., 86, 668 (1926)

Leonard and Frobishen, J. Urol., 15, I (1926); Trans. Amer. Assoc. Gen. Urol. Surg., 18, 333 (1925)

Leonara and Feirer, Dental Cosmos, 3, 559 (7927) 
Damon, Amer. J. Public Health, I7, 279 (1927)

Feirer and Leonard, J. Amer. Dent. Assoc., 1-17 (1927);

Dental Cosmos, Sept. 1-12 (1927)

"New and Non-official Remedies", Amer. Med. Assoc. Council on Chemistry and Pharmacy, 1932, p. 344

(3) Johnson and Hilbert, J. Amer. Chem. Soc., 51, 1526 (1929)

(4) Johnson and Bass, ibid., 52, 1146 (1930)

(5) Dunning, Dunning and Dreke, ibid., 53, 3466 (1931)

(6) Moness, Braker and Christiassen, J. A. Ph. A., 2l, 557 (1932)

(7) Suter and Hansen, J. Amer. Chem. Soc., 54, 4100 (1932)

(8) Miller and Read, ibid., 55, 1224 (1933)

(9) Poulsson "Pharmacology and Therapeutics", William Heineman, London, 1923

(10) Dyson, "Chemistry of Chemotherapy", John Wiley and Sons, Inc., New York, 1928

(11) Schaeffer and Tilley, J. Bacteriology, 12, 303 (1926); 14, 259 (1927)

(12) Zincke and Lenhart, Ann., 400, 1 (1924)

(13) Adams, "Organic Synthesis", John Wiley and Sons, Inc. N. Y. 1928, Vol. VIII, p. 92

(14) Tassinan, Gazz. chim. ital., 17, 83 (1887); 19, 343 (1889); $20,362(1890)$

(15) Hinsberg, Ber., 36, 107 (1903); German Patent 147,634; Cher. Zentr., 75, 130 (1904)

(16) Knoevenagel and Polack, Ber. 41, 3331 (1908) 
(17) Bourgeois, Rec. Tran. chim., 31, 32 (1912)

(18) Lecher, Ber., 58, 413 (1925)

(19) Zeigler, ibid., 23, 2469 (1890)

(20) Mauthner, ibid., 39, 1347 (1906)

(21) Leuckart, J. prak. chem., (2) 41, 192 (1890)

(22) Wohlfart, ibid., (2) 66, 553 (1902)

(23) Blanskma, Rec. tran. chim., 20, 127 (1901)

(24) Rogert and Stull, "Organic Synthesis", John Wiley and Sons, Inc., New York 1928, Vol. VIII, p. 64

(25) B., 6, 340

(26) Treadwell and Hall, "Analytical Chemistry", John Wiley and Sons, Inc., N. Y. 1930 , p. 76 


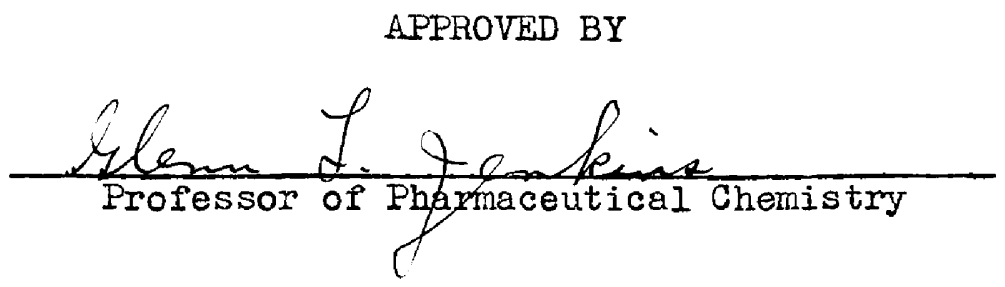

